\title{
DAMPAK PANDEMI COVID-19 TERHADAP PENGELOLAAN KEUANGAN NEGARA
}

\author{
Nanang Suparman \\ Universitas Islam Negeri Sunan Gunung Djati Bandung \\ Alamat korespondensi: n.suparman69@gmail.com
}

\begin{abstract}
The article aims to reveal the management of state finances policies to overcome the Covid-19 pandemic in Indonesia that has paralyzed the small and medium enterprise which was preceded by a decline in people's purchasing power. The sharp decline in supply and demand, in the manufacturing sector has disrupted supply chains and employment termination, resulting in a decline in state revenue from the tax sector. It is feared that the downturn national economic growth minus 5.32 percent in the second quarter could trigger a recession and economic crisis so that the response to the management of state finances is taken to anticipate possibility of tough or very tough situation. This article is designed based on qualitative method by using secondary data that investigate and analyze response to budget adjustments. Budget allocation is prepared for health infrastructure and various economic assistance for community empowerment, strengthening the economy of the business sector, and preparing for the sustainability of economic activities through the national economic recovery program dealing with invention of Covid-19 vaccine.
\end{abstract}

\begin{abstract}
ABSTRAK
Kajian ini akan mengungkapkan tentang kebijakan pengelolaan keuangan negara dalam mengatasi pandemi Covid-19 di Indonesia yang telah mengakibatkankan kelumpuhan sektor usaha kecil menengah yang dipicu menurunnya daya beli masyarakat. Dengan adanya penurunan supply dan demand yang tajam pada sektor industri manufaktur, telah mengakibatkan terganggunya rantai pasok dan pemutusan hubungan kerja, sehingga terjadi penurunan penerimaan negara dari sektor pajak. Pertumbuhan ekonomi nasional yang minus 5,32 persen pada kuartal kedua dikhawatirkan dapat memicu resesi dan krisis sehingga respon extraordinary pengelolaan keuangan negara ditempuh untuk mengantisipasi kondisi berat dan sangat berat yang mungkin bisa terjadi. Metode penelitian dengan pendekatan kualitatif menggunakan kajian literatur yang menginvestigasi dan menganalisis respon penyesuaian anggaran negara terhadap situasi abnormal. Pengalokasian anggaran ditujukan untuk infrastuktur kesehatan dan berbagai paket stimulus pemberdayaan masyarakat, penguatan sektor dunia usaha, dan penyiapan keberlanjutan kegiatan ekonomi melalui program pemulihan ekonomi nasional searah dengan upaya penemuan vaksin Covid-19.
\end{abstract}

KATA KUNCI:

Covid-19, Pengelolaan Keuangan Negara, Pemulihan Ekonomi

KLASIFIKASI JEL

E62, H51, H75

CARA MENGUTIP:

Suparman, N. (2021). Dampak pandemi covid-19 terhadap pengelolaan keuangan negara. Indonesian Treasury Review: Jurnal Perbendaharaan, Keuangan Negara dan Kebijakan Publik, 6(1), 31-42. 


\section{PENDAHULUAN}

Dalam jumpa pers pemerintah per 31 Desember 2020 disebutkan bahwa kondisi pandemi di Indonesia sangat mengkhawatirkan, dengan jumlah terinfeksi yang terkonfirmasi mencapai 743.198 orang dengan penambahan per hari 8.074 orang yang merupakan rekor tertinggi sejak kasus pertama diumumkan pada awal bulan Maret 2020, dengan jumlah kematian mencapai 22.138 orang (Merdeka, 2020). Pemerintah telah menempuh berbagai langkah untuk menekan penyebaran virus ini, baik melalui pendekatan kebijakan PSBB (Pembatasan Sosial Berskala Besar) maupun penerapan protokol kesehatan yang ketat namun sejauh ini upaya tersebut belum mampu menekan angka penyebaran dengan tren yang terus meningkat. WHO semakin mendorong setiap negara mengerahkan langkah apapun untuk mengatasi Covid-19 (Theguardian, 2020). Tantangan mendesak bagi negara-negara di dunia bagaimana menciptakan upaya extraordinary mengatasi Covid19 (Milne \& Xie, 2020). Mitigasi penanganan bencana kesehatan menjadi prioritas setiap pemerintahan di seluruh dunia sampai pada titik terendah penularan dan angka kematian (Walker et al., 2020)

Dampak ekonomi covid-19 lebih rumit dibandingkan krisis ekonomi global tahun 20082009 yang dirasakan para pemimpin negara di dunia dan para pengambil keputusan di sektor dunia usaha. Asumsi dampak ekonomi dari pandemi Covid-19 berupa guncangan akibat kondisi supply yang negatif (Chang \& McAleer, 2020; Hausmann, 2020). Terdapat dua kondisi yang menyebabkan guncangan ini. Pertama, para pekerja sektor manufaktur terpapar virus sehingga mereka berhenti bekerja, otomatis hal tersebut mengurangi kapasitas produksi. Seperti ditegaskan oleh (Atkeson, 2020, p. 2), bila 10 persen penduduk bumi terkena infeksi dapat mengakibatkan kekurangan tenaga kerja yang serius maka akan mempengaruhi infrastruktur ekonomi dan keuangan suatu negara. Kedua, aktivitas penduduk dibatasi untuk menekan penyebaran, namun sekaligus berdampak pada pengurangan produksi, penurunan perdagangan internasional, ekonomi kreatif, pariwisata dan kegiatan ekonomi lainnya.

Secara empiris penutupan kegiatan manufaktur di kawasan industri Jabodetabek selama tiga bulan mengakibatkan adanya pengurangan sebesar 87 persen output kapasitas produksi manufaktur Indonesia. Kondisi tersebut juga mengakibatkan pencapaian purchasing managers index pada bulan April 2020 hanya sebesar 27,5 merosot tajam dibanding pencapaian April 2020 sebesar 45,3 (Katadata, 2020b).

Penerimaan negara dari pajak ekspor barangbarang manufaktur signifikan bagi APBN, sehingga apabila terdapat tekanan ekspor dapat mengancam kestabilan postur APBN itu sendiri sebagaimana dikemukakan Menteri Keuangan Sri Mulyani Indarwati (DetikFinance.com, 2020). Suatu konstruksi pemodelan dampak ekonomi dari pandemic Covid-19 oleh Eichenbaum, Rebelo and Trabandt (2020, p. 28) menunjukkan bahwa kebijakan lock down atau social distancing untuk menekan penyebaran virus dapat menyelamatkan kehidupan, namun pada sisi yang lain dapat memperburuk resesi ekonomi karena diikuti oleh gelombang pemutusan hubungan kerja (PHK) secara masif.

Konfigurasi supply dan demand dalam ilmu ekonomi saling berkaitan, maka dampak penurunan supply juga berdampak pada penurunan demand bahkan lebih besar lagi (Guerrieri et al., 2020, p. 4). Hal tersebut dipertegas oleh keterangan Menteri Perencanaan Pembangunan Nasional (PPN/ Bapenas) Suharso Monoarfa bahwa dampak pandemik menciptakan penurunan daya beli masyarakat tercatat sebesar Rp362 Triliun. Kondisi tersebut menjadi faktor yang memperlambat pertumbuhan perekonomian nasional (Katadata, 2020a). Penurunan penerimaan negara juga terjadi secara global sebagai akibat kontraksi ekonomi yang hanya mencapai sebesar 3 persen (IMF (International Monetary Fund), 2020).

Pemerintah Indonesia merespon dengan cepat untuk menangani keadaan tersebut. Pada awal pandemi terjadi, Kementerian Keuangan mengambil sejumlah langkah konkret untuk menekan dampak negatif sosial ekonomi, diantaranya dengan merilis sejumlah paket kebijakan manajemen keuangan negara berupa: insentif pajak, perburuhan, ekspor-impor, keuangan dan perindustrian dengan tujuan untuk membantu dunia usaha bisa bertahan.

Namun demikian, kebijakan inti yang ditempuh pemerintah dan diharapkan dapat menyelamatkan perekonomian nasional dari jurang krisis belum dapat mengatasi penurunan berbagai indikator ekonomi makro dan kebangkrutan usaha di sektor riil pada skala mikro, kecil, menengah, dan besar sekalipun. Eskalasi pandemi yang semakin meningkat dan menjangkau pelosok wilayah menjadi kesulitan tersendiri bagi pemulihan ekonomi yang sedang terus diupayakan. Muro (2020) dalam penelitiannya menyimpulkan bahwa pemulihan ekonomi pada hampir semua negara yang terdampak pandemi akan lebih sulit dari apa yang dibayangkan.

Terdapat penelitian sejenis yang berkaitan dengan anggaran pemerintah untuk penanganan dampak pandemi (Skjesol, G. \& J. Tritter., 2020; Tombe, 2020) yang cukup menarik. Penelitian tersebut menganalisis penataan anggaran negara di mana lebih spesifik lagi tentang ketahanan fiskal 
yang banyak dialokasikan untuk ketahanan sosial, defisit anggaran kemudian berdampak pada pengurangan program-program kerja pemerintah yang bersifat pembangunan fisik.

Penelitian yang penulis lakukan adalah untuk mengetahui dan menganalisis:

1. pengelolaan anggaran negara yang dilakukan pemerintah di tengah tekanan pertumbuhan ekonomi yang mengalami kontraksi, tekanan pada sektor riil berupa kebangkrutan sektor usaha kecil menengah besar, dan

2. strategi pemulihan ekonomi nasional dijalankan dengan pendekatan extraordinary di tengah ketidakpastian tersebut.

3. Fenomena krisis kesehatan, sosial dan ekonomi secara simultan dimana hal tersebut yang belum pernah dialami pemerintah sebelumnya.

Kajian ini diharapkan memberi manfaat pengetahuan teoritikal maupun praktikal terkait upaya extraordinary pemerintah mengatasi defisit anggaran yang dimungkinkan secara manajerial maupun perundang-undangan.

\section{LANDASAN TEORI}

\subsection{Konsep Keuangan Negara}

Bacaan tentang keuangan negara terkait dengan hak pemenuhan kemampuan fiskal, akumulasi kekayaan pemerintah yang didapat dari penerimaan, instrumen peminjaman, tapi juga terkait pinjaman pemerintah. (Atmadja, 1986). Pemerintah mengemban tugas menjaga agar keuangan negara sehat dengan strategi menyeimbangkan pencapaian penerimaan terhadap pembiayaan pembangunan, mengelola defisit agar tidak terlalu lebar. Dalam perspektif kedaulatan ekonomi negara, defisit anggaran yang selalu berulang mencerminkan lemahnya fundamental dan daya saing bangsa. Pendapat lain dari Richard A. Musgrave (1989) memberikan pandangan terkait lingkup keuangan negara (public finance) mencakup ekonomi publik (economics of public sector), tidak terafiliasi pada pengertian sempit keuangan saja namun juga secara luas dalam kaitannya dengan pembiayaan dan penerimaan negara, distribusi pendapatan, dan ekonomi makro.

Pendapat yang sama juga dikemukakan Ulbrich (1993), cakupan luas studi keuangan negara berkolerasi dengan studi ekonomi pada sektor publik sedangkan domain teknis terkonsentrasi pada kegiatan penerimaan, pengeluaran dan budgeting. Pada perspektif lain, Suparmoko (2013) memandang keuangan negara sebagai bentuk kajian terkait dampak anggaran negara pada perekonomian makro, khususnya dampak yang ditimbulkan pada sasaran aktivitas pertumbuhan ekonomi, pengendalian harga, pemerataan pendapatan masyarakat, pemenuhan pekerjaan bagi masyarakat.

\subsection{Pengelolaan Anggaran}

Pengelolaan anggaran memuat sitematika perencanaan, pengaturan, pengalokasian, pengawasan dan feedback keuangan negara yang disusun secara sistematis berdasarkan perundangan yang berlaku.

Pengelolaan anggaran mengacu pada visi perencanaan pembangunan dengan penetapan tujuan yang terukur, secara teknis pengelolaan anggaran memuat perencanaan, pengawasan dan peng-administrasian (Granof et al., 2016; Hansen \& Mowen, 2007). Instrumen anggaran sebagai tolak ukur sejauhmana capaian program-program pemerintah dapat direalisasikan.

Terkait dampak ekonomi pandemi Covid-19, tata kelola anggaran pemerintah menjadi tumpuan agar dapat terhindar dari krisis sekaligus dapat mempertahankan kesinambungan jaring pengaman sosial bagi masyarakat tidak mampu, dan mampu merevitalisasi keterpurukan dunia usaha dengan strategi pemberian stimulus secara tepat sasaran dan tepat waktu. Dalam kondisi yang buruk dan membahayakan ekonomi negara, pemerintah melalui Kementerian Keuangan mampu merumuskan langkah-langkah strategis dari sisi payung hukum terkait kebijakan defisit anggaran yang melebar, pengamanan anggaran melalui penghematan dan realokasi anggaran yang diharapkan mampu menjadi alat untuk melalui kondisi skenario berat dan sangat berat.

Berdasarkan penjelasan tersebut, penelitian ini akan membahas tata kelola anggaran pemerintah yang terkena dampak tekanan Covid-19 dan bagaimana strategi pemulihan ekonomi nasional dijalankan.

\section{METODOLOGI PENELITIAN}

Kajian tentang pengelolaan keuangan negara yang terdampak Covid-19 menggunakan metode kualitatif dengan teknik pendektan survei literatur akademik melalui daring. Metode kualitatif dipilih dengan argumen tersedianya ruang penelitian berupa kedalaman dan ketajaman analisis dalam mengungkapkan fenomena serta fakta terkait dampak pandemi Covid-19 terhadap pengelolaan keuangan negara. Pendekatan penelitian dilakukan dengan analisis dokumen (Bowen, 2009), dimana peneliti mengakses google scholar, lembaga kajian, jurnal dan media masa terkait hasil kajian, informasi, hasil penelitian, dokumen kementerian, dokumen lembaga internasional, analis kebijakan pengelolaan keuangan negara yang terdampak pandemi. 
Pemenuhan kriteria keabsahan data dalam penelitian ini dilakukan dengan cara membagi dua bagian dalam dua keabasahan, yaitu: keabsahan internal dan keabsahan eksternal (Creswell, 2002). Keabsahan internal mencakup (i) triangulasi data, dalam konteks penelitian ini ialah data yang telah terkumpul melalui wawancara, pengamatan, dan analisis dokumen ditelaah pola keterhubungannya. (ii) Pemeriksaan oleh rekan sejawat, dan (iii) mengklarifikasi prasangka peneliti terhadap subjek yang dikaji, dimana semua harus berjalan secara natural tanpa adanya intervensi langsung maupun tidak langsung. Adapun keabsahan eksternal mencakup (i) peneliti menjelaskan fokus penelitian, peran peneliti, posisi informan, dasar pengumpulan data, dan konteks untuk mengumpulkan data (ii) seluruh tahap penelitian ini diperiksa dengan cermat oleh tim editor jurnal dan judgement ahli (reviewer) yang berpengalaman dalam metode penelitian kualitatif.

Langkah penelitian dilakukan dalam lima langkah. Pertama, penulis menemukan masalah pengaruh ekonomi dari penyebaran Covid-19 ini yang berbeda dari krisis ekonomi sebelumnya. Kedua, mengumpul-kan data sekunder tentang perkembangan up to date Covid-19 di Indonesia, dampak ekonomi yang ditimbulkannya, dan realokasi anggaran pemerintah yang diperoleh dari publikasi ilmiah dan informasi resmi dari kementerian keuangan, wawancara daring kepada informan key person dilakukan untuk memastikan keabsahan data sekunder yang telah dirilis. Ketiga, mengklasifikasi dan menyeleksi data yang relevan dengan pengelolaan keuangan negara untuk penanganan Covid-19. Keempat, analisis data dengan mengintrepretasikan kajian utama pengelolaan keuangan negara berupa aneka stimulus dan pengalokasian bagi pemulihan perekonomian nasional. Kelima, menarik kesimpulan dari kajian ini.

\section{HASIL PENELITIAN}

Tata kelola anggaran negara sangat krusial untuk mencapai tujuan pembangunan bidang ekonomi dimana secara konkret dapat diukur melalui pencapaian kesejahteraan sosial masyarakat (Jaelani, 2018; Rossen, H.S. \& Gayer, 2008). Fenomena serempak terkait tata kelola keuangan negara di seluruh dunia sekarang ini dialihkan untuk menyelesaikan masalah pandemi global Covid-19 yang sangat berpotensi mengakibatkan krisis ekonomi dan resesi di seluruh dunia (Faridi, 1983). Covid-19 telah secara nyata menjadi ancaman pada perekonomian Indonesia dimana secara makro pertumbuhan ekonomi pada tahun 2019 sebesar 5,3-5,4 persen harus terkoreksi menjadi 2,97 persen pada kuartal satu tahun 2020 dan mengalami konstraksi menjadi -5,32 persen pada Kuartal 2 tahun 2020. Gelombang penularan yang intens Covid-19 mengakibatkan perlambatan ekonomi secara ekstrim dengan efek domino menghentikan sebagian besar aktivitas ekonomi (Engkus, 2020).

\subsection{Strategi Baru APBN Versi Dampak Covid-19}

Covid-19 sebagai masalah kesehatan kemudian bertransisi menjadi masalah sosial dan ekonomi dalam tempo yang sangat cepat. Mengacu pada laporan Bank Dunia (Worldbank.org, 2020) Indonesian Economic Prospect Edition July 2020 yang dinamai "The long road to recovery" kinerja ekonomi Indonesia pada tahun ini hanya tumbuh nol persen. Tetapi terdapat skenario kedua yang lebih buruk dimana ekonomi Indonesia mengalami kontraksi sebesar -2 persen (minus dua persen) yang dipengaruhi lingkungan eksternal berupa resesi global yang lebih buruk ditambah faktor Pembatasan Sosial Berskala Besar (PSBB) yang lebih ketat di ibu kota negara dan di sejumlah daerah yang langsung mempengaruhi produk domestik bruto. Upaya pemulihan ekonomi yang dilakukan akan terhambat oleh gelombang pandemi yang belum berkesudahan.

Respon strategis pemerintah melalui perumusan dasar hukum kebijakan dinilai sangat tepat untuk memberikan jaminan bagi aktor pengambil keputusan agar tidak mengalami tuntutan hukum diluar konteks diskresi yang dimiliki pejabat pemerintah (traumatik pejabat pengguna diskresi kebijakan pada kasus Bank Century). Dengan publikasi regulasi baru untuk kebijakan penanganan Covid-19 akan memberikan kepastian hukum bagi eksekutif dalam bekerja yang penuh dengan resiko tersebut. Tekanan sosial ekonomi yang luar bisa (under high pressure) menuntut segera adanya penataan dengan memformat ulang postur anggaran negara yang adaptif menghadapi turbulensi perekonomian dampak pandemi tersebut.

Tekanan signifikan pada sisi belanja mendorong adanya APBN Perubahan sehubungan dengan meningkatnya kebutuhan nasional yang bersifat urgen untuk mengatasi bencana kesehatan masyarakat, memperluas jaring pengaman sosial dengan menekankan pemerataan dan tepat sasaran. Peninjauan struktur APBN ditempuh melalui penetapan Peraturan Presiden Nomor 54 Tahun 2020, dan kemudian kembali diubah dengan dengan terbitnya Peraturan Presiden Nomor 72 Tahun 2020.

Akumulasi penyebaran pandemi Covid-19 secara langsung menekan dengan hebat perekonomian daerah maupun pusat sebagaimana pada tabel 1, pertumbuhan ekonomi Triwulan I2020. Atas dasar unpredictable situation, Bank Indonesia (2020) menetapkan proyeksi pertumbuhan ekonomi Indonesia sebesar 4,2 
sampai dengan 4,6 persen dengan perbandingan lebih tinggi dari proyeksi dari ADB dan IMF, dimana ADB memproyeksikan pertumbuhan 2,5 persen, sedangkan IMF memberikan proyeksi pesimistis dengan perkiraan sebesar 0,5 persen.

TABEL1. Perkiraan Pertumbuhan Ekonomi dan Laju Inflasi Indonesia

(Dalam Persen) Tahun 2020-2021.

\begin{tabular}{|c|c|c|}
\hline \multicolumn{1}{|c|}{ Indikator } & 2020 & 2021 \\
\hline Pertumbuhan ekonomi $^{1}$ & $4,2-4,6$ & $5,2-5,6$ \\
\hline Pertumbuhan ekonomi $^{2}$ & 0,5 & 8,2 \\
\hline Pertumbuhan ekonomi $^{3}$ & 2,5 & 5,0 \\
\hline Inflasi $^{1}$ & $3,0 \pm 1,0$ & $3,0 \pm 1,0$ \\
\hline Inflasi $^{2}$ & 3,1 & 3,0 \\
\hline Inflasi $^{3}$ & 3,0 & 2,8 \\
\hline
\end{tabular}

Sumber:

1) Publikasi Laporan Perekonomian Indonesia 2019, Bank Indonesi

2) Publikasi World Economic Outlook Database April 2020, International Monetary Fund

3) Publikasi Asian Development Outlook (ADO) 2020, Asian Development Bank (ADB)

Tekanan berat pada APBN akibat pandemi mendorong pemerintah merumuskan dan mengimplementasikan strategi baru pada APBN 2020 yang sedang berjalan. Item-item yang terangkum dalam strategi baru meliputi: pemberian insentif perpajakan (super deduction bagi aktivitas bidang kejuruan dan litbang), insentif keringanan pajak untuk investasi dengan nilai tertentu, dan bantuan modal diperuntukan bagi perintis usaha kecil. Terdapat juga bentuk strategi untuk meningkatkan kualitas SDM dan perlindungan sosial.

Kontinuitas pandemi yang belum ada tanda akan berakhir dan spekulasi penemuan vaksin dalam wacana publik yang belum ada kepastian adalah konstektualitas urgensi strategi baru APBN 2020 tersebut. Pergeseran skala prioritas telah dilakukan sebagaimana tercantum pada APBNP 2020 (Perpres No.72 Tahun 2020), antara lain berupa: kebijakan pemberian insentif pajak berlaku untuk wajib pajak terdampak pandemi, peluncuran Kartu Indonesia Pintar Kuliah, Kartu Pra Kerja, dan Kartu Sembako dengan sasaran penerimanya diperluas sebagai dampak PHK akibat pandemi, juga pemberian dana transfer daerah dan dana desa diutamakan bagi penanganan pandemi Covid-19. Sebelum pandemi mewabah, pemerintah telah memulai proyek lima destinasi wisata super prioritas strategi baru APBN di antaranya memastikan progres pembangunannya tetap dilanjutkan.

Sisi penerimaan pada APBN sebagai tulang punggung untuk pendanaan kegiatan-kegiatan pembangunan nasional. Secara klasikal penerimaan yang dihimpun dari pajak dan non pajak tidak dapat memenuhi alokasi pengeluaran untuk kegiatan pembangunan pada setiap tahunnya sehingga mendorong pemerintah berupaya mencari secara intensif berbagai sumber pendapatan agar penerimaan negara dapat terus ditingkatkan sehingga kemandirian APBN dapat terwujud menjauhi akses sumber pembangunan dari utang dengan pihak lain. Tahun 2020 penerimaan negara mendapatkan kontraksi cukup besar sejak ditetapkannya Perpres No.72 Tahun 2020 tentang perubahan anggaran karena pandemi Covid-19.

Tabel 2 Penerimaan Negara Tahun 2016-2020 (Triliun Rupiah)

\begin{tabular}{|l|r|r|r|r|r|}
\hline \multirow{2}{*}{ Keterangan } & \multicolumn{1}{|c|}{$\mathbf{2 0 1 6}$} & $\mathbf{2 0 1 7}$ & $\mathbf{2 0 1 8}$ & \multicolumn{1}{c|}{$\mathbf{2 0 1 9}$} & \multicolumn{1}{c|}{$\mathbf{2 0 2 0}$} \\
\cline { 2 - 6 } & \multicolumn{1}{|c|}{ LKPP } & \multicolumn{1}{c|}{ LKPP } & \multicolumn{1}{c|}{ LKPP } & \multicolumn{1}{c|}{ Realisasi } & \multicolumn{1}{c|}{ APBNP } \\
\hline A. Penerimaan Negara dan Hibah & $\mathbf{1 5 5 5 , 9 3}$ & $\mathbf{1 6 6 6 , 3 8}$ & $\mathbf{1 9 4 3 , 6 7}$ & $\mathbf{1 9 5 7 , 2 0}$ & $\mathbf{1 6 9 9 , 9 5}$ \\
\hline 1. Penerimaan Dalam Negeri & 1546,95 & 1654,75 & 1928,11 & 1950,40 & 1698,65 \\
1. Penerimaan pajak & 1284,97 & 1343,53 & 1518,79 & 1545,30 & 1404,51 \\
2. Penerimaan bukan pajak & 261,98 & 311,22 & 409,32 & 405,00 & 294,14 \\
2. Hibah & 8,99 & 11,63 & 15,56 & 6,80 & 1,30 \\
\hline
\end{tabular}

Sumber: Perpres No.72 Tahun 2020, LKPP 2016, 2017, 2018, dan APBN Kita Januari 2020, Kemenkeu

Tren yang berkembang pada penerimaan negara cenderung meningkat setiap tahun seiring dengan belanja negara dan inflasi yang turut meningkat. Dampak pandemi pada tahun 2020 mengakibatkan penyesuaian target penerimaan yang mengalami penurunan cukup signifikan. Untuk tahun 2020, pendapatan negara diperkirakan hanya mencapai Rp1.699,95 triliun atau turun 13,14 persen dari realisasi APBN 2019. Sisi APBN dari penerimaan mencakup raihan sektor pajak, Penerimaan Negara Bukan Pajak (PNBP) dan hibah. Penerimaan pajak merupakan andalan penerimaan negara, dan selanjutnya bersumber dari PNBP dan dari hibah. Sebagai tambahan, data dalam tabel di atas menunjukkan bahwa penerimaan dari hibah sebagai komplementer.

\subsection{Penguatan Sisi Demand}

Aspek lain dari strategi baru APBN Versi Covid19 yakni dengan mencegah keterpurukan ekonomi masyarakat dari sisi demand masyarakat yang semakin melemah yang dapat memicu lonjakan angka kemiskinan. Dalam kondisi tersebut, kondisi ini dapat dengan mudah memicu chaos. Dengan 
alasan dan latar belakang kondisi tersebut, Pemerintah menyalurkan sejumlah bantuan guna meningkatkan daya beli masyarakat. Rincian anggaran untuk alokasi program jaring pengaman sosial kemudian membantu sektor papan dalam bentuk subsidi pembiayaan rumah bagi masyarakat terdampak. Pada intinya kebijakan penguatan sisi demand berfungsi sebagai barrier akselerasi dampak ekonomi pada masyarakat dengan daya beli yang terus menurun. Dari berbagai sumber text book, berbagai kebijakan jaring pengaman sosial yang menyasar masyarakat bawah (grass root) dalam kondisi pandemi dinilai sebagai langkah yang tepat dan adil. Namun demikian, permasalahan teknis dalam hal akurasi data sasaran kebijakan dan urgensi waktu penyaluran bantuan menjadi masalah tersendiri yang belum terpecahkan.

Secara konseptual, demand menjelaskan tentang jumlah permintaan ketersediaan produksi pada kondisi meningkat atau menurun diikuti dengan penyesuaian harga sebagi cerminan sisi pengeluaran di masyarakat (Mankiw, 2009). Gambaran demand pada masyarakat Indonesia dapat dilihat bahwa lebih dari 60 persen dari PDB merupakan konsumsi dan distribusi. Dengan struktur ekonomi masyarakat lebih didominasi masyarakat berpendapatan rendah, maka secara rasional, prioritas langkah tepat kebijakan pemerintah adalah dengan memberikan perlindungan sosial dalam bentuk bantuan sosial. Bantuan sosial untuk mengcover kebutuhan dasar minimal menyasar layer masyarakat yang paling rentan sosial ekonominya akibat dampak Covid-19. Skema perlindungan sosial menjadi urgen untuk secepatnya disalurkan dengan pagu anggaran sebesar Rp203,9 triliun kemudian disusul skema insentif perumahan MBR (Badan Kebijakan Fiskal, 2020).

Sasaran penerima bantuan Program Keluarga Harapan (PKH) diperluas melalui perbaikan basis data agar efektifitasnya bisa lebih dapat dipertanggungjawabkan dan anggaran yang disalurkan lebih maksimal. Selain itu, untuk program distribusi pangan, pemerintah juga meningkatkan pagu anggaran dengan tujuan untuk meringankan biaya rumah tangga berupa keringanan tagihan PLN, program pemberdayaan untuk klaster wilayah di luar ibu kota, dan juga alokasi penambahan anggaran khusus untuk sasaran penerima bansos sebesar Rp6,8 triliun, program penting lainnya mulai dari Bantuan Langsung Tunai (BLT) menyusul Dana Desa Rp31,8 triliun dan Kartu Pekerja sebesar Rp20 triliun. Perbaikan sisi demand masyarakat sebagai kebijakan tepat sasaran di tengah pandemi yang terus berlangsung sangat krusial demi menciptakan ketahanan ekonomi masyarakat, maka dalam konteks ini pengelolaan anggaran mencerminkan politik anggaran pro-poor dengan keseimbangan antara penanganan sektor kesehatan dan sektor ekonomi, dengan tetap memperhatikan keseimbangan antara pengendalian rem dan pengendalian gas.

Kebijakan pemerintah terkait stimulus ekonomi seperti diuraikan pada Lampiran 1, dapat dianalisis dengan konstruksi pemikiran awal yang beranjak dari perkembangan krisis kesehatan menjadi krisis ekonomi. Dampak sosial ekonomi yang menimpa masyarakat di Indonesia sudah meluas pada berbagai strata dan segmen masyarakat. Pembiayaan program stimulus ekonomi tentu menambah tekanan pada APBN dengan semakin melebarnya defisit anggaran berjalan (Sheiner, 2020). Namun demikian, berapapun penambahan kebutuhan anggaran untuk pemulihan dampak pandemi Covid-19 harus diupayakan pemenuhannya karena menyangkut ancaman kematian warga negara dan untuk menjauhkan dari kemungkinan krisis sosial ekonomi yang dampaknya jauh lebih buruk lagi. Rasionalitas urgensi stimulus ekonomi yang mencakup sektor fiskal, non-fiskal, dan sektor keuangan diyakini akan memberikan kemanfaatan yang besar dari sebuah alternatif kebijakan di tengah situasi yang tidak normal. Informasi dari pejabat pusat Kementerian Keuangan melalui wawancara tertulis secara daring menjelaskan,

"Program stimulus ekonomi yang terkena dampak Covid-19 bertujuan untuk melindungi, mempertahankan dan meningkatkan kemampuan ekonomi para pelaku usaha dari sektor riil dan sektor keuangan dapat melanjutkan aktifitas usahanya".

Dari keterangan wawancara tersebut dapat disimpulkan Pemerintah telah berupaya maksimal untuk mencegah dan meminimalisir dampak krisis pandemi menimpa dunia usaha dan pada level tertentu mendorong terjadinya kebangkitan dunia usaha, menghindari kondisi sebaliknya yang berupa kebangkrutan dan keterpurukan dimana jika kondisi demikian terjadi sakan menimbulkan efek domino banyaknya masyarakat yang kehilangan pekerjaan dan dampak susulannya akan lebih buruk lagi.

Secara keseluruhan, kebijakan pembiayaan untuk penanganan Covid-19 menimbulkan konsekuensi alokasi beban anggaran yang relatif besar dengan menyedot anggaran sebesar Rp579,8 triliun selama tahun 2020. Secara faktual, krisis ekonomi yang terjadi menimpa semua lapisan pelaku penggerak ekonomi nasional. Para pelaku usaha dari dengan modal kecil sampai dengan modal besar mengalami keadaan yang sama yang dipengaruhi dengan tidak adanya daya serap produksi oleh konsumen. Pemutusan hubungan kerja yang terus terjadi memperburuk keadaan. Dengan demikian, penanganan dampak pandemi melalui strategi stimulus ekonomi memerlukan sinkronisasi dan sinergitas antara pendekatan 
makro ekonomi, jaring pengaman sosial, komunikasi politik pemerintah, perlindungan kesehatan (Loayza \& Pennings, 2020).

Kebijakan mitigasi pandemi Covid-19 di Indonesia dinilai belum optimal. Hal ini merujuk pada respon pemerintah yang cukup longgar pada awal kejadian dengan tidak memperketat kedatangan orang asing yang menjadi suspect terkena virus, dianggap menjadi salah satu faktor pemicu penyebaran di dalam negeri dan hingga saat ini terus meluas. Kebijakan keamanan nasional memerlukan ketegasan untuk menangkal ancaman termasuk ancaman penyebaran virus. Dampak lemahnya kebijakan pengetatan keluar masuknya orang asing terutama dari negara asal pandemi menjadi beban pada aspek tata kelola keuangan negara yang dijalankan Kementerian Keuangan Republik Indonesia yang dituntut menyiapkan alokasi anggaran ekstra di tengah situasi perokonomian dunia yang tengah lesu bahkan ketika pandemi belum mewabah sekalipun. Dalam konteks tersebut pemerintah dapat melakukan benchmarking pada negara-negara yang relatif berhasil menangani pandemi misalnya Thailand, Korea Selatan, Vietnam, dan bahkan China sebagai negara pertama yang menderita wabah tersebut.

Stimulus ekonomi digulirkan pemerintah salah satunya memperhatikan situasi menurunnya sejumlah indikator makroekonomi seperti pertumbuhan ekonomi yang minus, menurunnya kinerja perdagangan, menurunnya tingkat daya beli konsumen. Pada segmen moneter dan keuangan, profil pasar modal ekuitas mengalami penurunan kinerja yang signifikan dimana tercatat pada periode Januari s.d. Maret 2020 sebagai titik terendah. Pada sisi lain, terjadi aliran keluar modal asing yang berkolerasi pada meningkatnya yield obligasi pemerintah jangka pendek. Kebijakan stimulus fiskal dilakukan dari sisi insentif perpajakan dan juga melalui realisasi APBN, dengan asumsi adalah bahwa penurunan pajak secara langsung berkorelasi pada penurunan biaya produksi, akan tetapi tidak secara otomatis mendorong produsen meningkatkan produksinya. Kondisi ini akan menimbulkan adanya disrupsi pada sisi demand. Pada konteks demikian, fungsi belanja pemerintah menjadi krusial untuk merevitalisasi sisi permintaan yang tergambar pada daya beli masyarakat yang membaik, sehingga produksi dari sektor usaha kecil, menengah dan manufaktur dapat terserap.

Analisis pada stimulus fiskal dapat dijelaskan bahwa terdapat karakteristik penting dimana program tersebut diarahkan untuk menyeimbangkan antara pihak konsumen dan produsen pada beberapa sektor yang terdampak, di antaranya sektor kesehatan, UMKM, perdagangan, pariwisata dan manufaktur. Strategi stimulus fiskal berupa (i) pembiayaan untuk menghentikan pandemi, (ii) transfer bantuan tunan/non tunai bagi masyarakat rentan rawan daya beli, (iii) insentif bagi sektor dunia usaha untuk mengurangi beban perusahaan dengan pengurangan dan penundaan pembayaran pajak termasuk di dalamnya pembebasan biaya registrasi usaha, dan (iv) pemberian insentif fiskal temporal bagi sektor usaha yang sangat terdampak seperti pariwisata, penerbangan, kuliner, perhotelan, dan transportasi semua moda. Program stimulus membutuhkan alokasi anggaran yang besar di tengah kondisi defisit anggaran terus bertambah. Bagaimana strategi pemerintah untuk membiayainya? Melalui wawancara tertulis, pejabat Kepala Biro Komunikasi dan Layanan Informasi Kementerian Keuangan menjelaskan bahwa, "Program stimulus ekonomi ini bisa terwujud oleh sebab pihak kementerian melakukan penghematan anggaran dengan refocusing dan realokasi pos pengeluaran pada APBN, dengan harapan dana stimulus dapat memberikan dampak positif pada ekonomi masyarakat. Penghematan anggaran yang dapat dihimpun sebesar Rp. 190 triliun dan Rp55 Triliun dari realokasi". Dari informasi tersebut, dapat disimpulkan bahwa pemerintah mampu menciptakan respon pengelolaan anggaran yang memadai untuk menghindari krisis ekonomi yang bisa mungkin terjadi.

\subsection{Komparasi Kebijakan dengan Negara Lain.}

Bagaimana respon awal Pemerintah Indonesia terhadap kemunculan pandemi Covid-19 menunjukkan sikap yang kurang memenuhi sense of urgency, berbanding terbalik dengan apa yang dilakukan negara ASEAN lainnya yakni Vietnam di mana dari awal menunjukkan sikap yang sigap dan sungguh-sungguh bahwa kejadian di Wuhan akan menyebar dan menjadi ancaman serius. Pemerintah Vietnam dinilai berhasil mendayagunakan "the golden time" dalam upaya mengatasi merebaknya virus di dalam negeri dengan cara menutup seluruh pintu masuk bandara dan pelabuhan dan tidak mengijinkan penerbangan dari dan ke Wuhan sebagai upaya pencegahan masuknya orang-orang asing sebagai pembawa virus (Huynh, 2020).

Vietnam menjalankan dan bahkan lebih maju dari saran WHO dalam meredam pandemi, dintaranya sosialisasi dan mewajibkan masyarakat memakai masker, intensifikasi tes masal di seluruh juridiksi wilayah negera dengan jumlah mencapai kurang lebih 280.000, dan kebijakan karantina diberlakukan di sebagian wilayah sejak awal Februari 2020. Temuan kasus di Negara Vietnam hanya sejumlah 10 orang yang positif terinfeksi (CNN Indonesia, 2020).

Pemberlakuan kebijakan lockdown dan pengetatan yang diawasi oleh unsur kepolisian dan militer telah membuahkan hasil positif. Untuk pertama kalinya sejak 23 April 2020 Vietnam melaporkan 0 kasus penularan harian sekaligus 
mengakhiri fase lockdown dan mulai melonggarkan kebijakan pembatasan sosial. Penyebaran virus yang sudah berhasil ditekan menjadi landasan untuk kembali normalisasi kehidupan sosial ekonomi, transportasi semua mode membuka ruterute perjalanan seperti biasa, aktivitas ekonomi, kegiatan belajar di sekolah dan universitas dengan tatap muka. Namun demikian, pemerintah masih tetap menjalankan protokol kesehatan, dan larangan perjalanan internasional masih berlaku (IMF, 2020b).

Keberhasilan otoritas Vietnam dalam mitigasi bencana kesehatan, bukan berarti tanpa dibebani dengan dampak soisal ekonomi.sektor usaha baik mikro maupun makro. Turbulensi menimpa sekitar 65 persen unit usaha hampir mengalami kebangkrutan. Bahkan sekitar 37.000 unit usaha real bangkrut sejak Januari hingga Maret 2020, pencapaian terburuk dimana jumlah perusahaan yang tutup lebih tinggi dari jumlah perusahaan yang baru terdaftar sepanjang dekade.

Seperti halnya kebijakan yang ditempuh Indonesia, otoritas Vietnam juga merilis stimulus ekonomi dalam rangka mengeliminir dampak sosial ekonomi yang menimpa pelaku bisnis dan masyarakat, implementasi kebijakan pemerintah Vietnam berupa Decree 41/2020/NDCP (Decree 41) pada 8 April 2020. Konten pada Dekrit tersebut mencakup insentif-insentif yang diberikan pemerintah untuk beberapa sektor usaha, terdiri dari UMKM, industri pengolahan pengolahan makanan dan minuman, kerajinan rakyat, tenun sutra, furniture tradisional dan modern, pariwisata, otomotive, penyelengara diklat, perumahan bersubsidi, layanan buruh dan tenaga kerja, agen perjalanan, operator tur, kegiatan hiburan, film, industri pendukung, kecil dan perusahaan menengah, serta perbankan. Pemerintah mengalokasikan dana sebesar VND 27 triliun (US\$ 1,6 miliar) untuk menjalankan insentif-insentif tersebut (Falak. , 2020).

Pemulihan ekonomi pada titik tertentu lebih cepat berjalan di Vietnam. Hal ini dimungkinkan oleh adaptasi kebiasaan baru menuju kehidupan normal tanpa pembatasan yang terlalu ketat. Kondisi di Indonesia, hingga memasuki tahun 2021, kebijakan pembatasan sosial untuk menekan tren penularan Covid-19 yang semakin progresif berkolerasi negatif dengan kenormalan aktivitas perusahaan. Hasil survey mutakhir (BPS, 2020) mendeskripsikan 40 persen perusahaan yang disurvey telah berhenti beroperasi sisanya beroperasi dengan varian pengurangan kapasitas yang mencakup jam kerja, mesin dan tenaga kerja. Pada perusahaan baik Usaha Menengah Kecil (UMK) maupun Usaha Menengah Besar (UMB) yang masih bisa bertahan untuk beroperasi dihadapkan pada masalah yang sama yang sangat krusial diantaranya 80 persen dihadapkan pada penurunan permintaan sebagai konsekwensi dari pelanggan/klien yang juga terdampak Covid-19.

Berbagai kajian akademik dan intrepretasi hasil survei terkait dampak Covid-19 terhadap eksistensi dunia usaha dapat dijadikan ukuran atau kriteria untuk menganalisis manfaat program stimulus ekonomi bagian dari grand design pemulihan ekonomi nasional secara holistik. Terhadap paket bantuan social yang telah disalurkan termasuk stimulus ekonomi pada sektor dunia usaha maka pemerintah perlu segera melakukan evaluasi. Tujuan utama dilakukannya evaluasi pengeluaran APBN dalam penanganan Covid-19 untuk menata serta dapat meningkatkan akuntabilitas pertanggung jawaban keuangan negara. Pada berbagai kesempatan Presiden Joko Widodo sangat menekankan efektivitas bantuan dengan memperhatikan kesegeraan penyampaiannya dan mengawasi seoptimal mungkin dana bantuan dari upaya penyalahgunaan, kepada apparat penegak hukum beliau secara gamblang meminta menindak tegas dan keras kepada siapapun oknum yang memotong atau mengkorupsi dana bantuan untuk penanggulangan Covid-19 ini.

Secara konseptual, evaluasi program menilai keberhasilan sasaran, tetapi tidak mengevaluasi sasaran yang sudah disepakati (Suparman et al., 2019). Spesifikasi sasaran (goals) kemudian ditetapkan karena sasaran-sasaran merupakan kriteria keberhasilan program, maka harus dinyatakan secara spesifik agar diperoleh kriteria tolak ukurnya. Namun seringkali tujuan/sasaran tersebut hanya dinyatakan secara umum atau general dengan lingkup jangka panjang, dan bahkan terkadang kontra produktif dan tidak terkait dengan aktifitas-aktifitas program. Selanjutnya untuk mengoptimalkan tujuan/sasaran kebijakan pengelolaan anggaran bagi yang terdampak Covid19 dalam kerangka evaluasi program, maka mutlak diperlukan institusionalisasi evaluator dimana berperan sebagai wadah, sebagai proses, sebagai perilaku dan sebagai alat untuk mencapai tujuan.

Berkaitan dengan setting tujuan evaluasi pengelolaan anggaran dampak covid-19 dan untuk mengetahui tingkat pemahaman unsur evaluator terhadap tujuan utama evaluasi tersebut, maka seluruh komponen evaluator yang terdiri dari Badan Pemeriksa Keuangan (BPK), Badan Pengawasan Keuangan dan Pembangunan (BPKP), Inspektorat Jenderal Kementerian Keuangan, Inspektorat Jenderal Kementerian Sosial dan Inspektorat Jenderal Kementerian terkait harus memahami secara komprehensif tujuan utama dari kebijakan evaluasi pengelolaan anggaran negara dampak Covid-19, yaitu untuk mengevaluasi (mengaudit) tata kelola keuangan negara dalam penanganan pandemi agar selaras dan tidak bertentangan dengan Undang-Undang Keuangan Negara sebagai landasan hukum positif. 
Spesifikasi kegiatan evaluasi kebijakan pengelolaan anggaran untuk penanganan dampak sosial ekonomi yang dilkukan oleh evaluator disaratkan mengandung tujuan yang harus terperinci, dalam konteks ini tujuan yang harus dilakukan evaluator adalah: 1) memahami, menganalisadan memberikan penilaian terhadap perkembangan daya serap anggaran untuk penaganan terdampak pandemi dari masingmasing evaluator, 2) merumuskan kebijakan yang terkait dengan tata kelola anggaran baru versi Covid-19 yang dilakukan oleh stakeholder Kementerian dan Lembaga leading sector penanganan Covid-19 tingkat pusat dan daerah, dan 3) memetakan kinerja masing-masing instansi unit utama yang diberi mandat untuk mengevaluasi kebijakan perubahan pengelolaan angggaran.

Gelombang krisis kesehatan membawa dampak terhadap sendi-sendi kehidupan masyarakat dengan perubahan yang sangat cepat yang sebelumnya tidak diduga dan tidak diharapkan sama sekali dimana menurunnya aktivitas ekonomi di mayoritas negara di dunia, termasuk di Indonesia. Perumusan kebijakan untuk menelurkan upaya extraordinary pemerintah dalam penangannya maka dibutuhkan pangkalan data yang valid dan akurat untuk menciptakan prakondisi agar sasaran kebijakan dapat dicapai dengan tingkat keberhasilan yang tinggi. Evaluasi cross sectoral lintas Kementerian dan Lembaga penanganan dampak Covid-19 terhadap pegiat usaha kecil maupun besar sebagai wujud experimental statistics dengan maksud untuk menyediakan indikator mutakhir (an early indicator) tentang pelaku usaha yang terdampak pandemi Covid-19. Monitoring dan evaluasi dapat dilakukan melalui platform online survey untuk menjaring informasi tentang fenomena sosial dan sekaligus kuantifikasi data terkait kondisi perusahaan di tengah pandemi yang dapat dilihat secara multi aspek diantaranya operasional, aspek perburuhan, segi income, kesulitan yang dihadapi, tingkat adaptasi, membangun optimisme, hingga bantuan yang dibutuhkan.

\section{KESIMPULAN DAN SARAN}

Penelitian ini bertujuan untuk mengungkapkan dan menganalisis implikasi pandemi Covid-19 terhadap pengelolaan keuangan negara. Bagian-bagian yang dianalisis antara lain dampak determinasi Covid-19 yang terus menunjukkan tren peningkatan, kebijakan pengelolaan keuangan negara di tengah pandemi, dan model respon extraordinary yang diambil pemerintah terkait pengelolaan keuangan negara.

Hasil kajian menunjukkan bahwa atas dasar situasi yang tidak menguntungkan tersebut, Pemerintah Indonesia telah mengeluarkan kebijakan pengelolaan anggaran untuk penanganan epidemi ini melalui pendekatan strategi baru pengelolaan APBN yang menguatkan sisi penerimaan dan relevansi sisi pengeluaran yang selaras dengan penanganan Covid-19. Stimulus perekonomian secara intensif dilakukan dengan alokasi anggaran yang diperoleh dari berbagai sumber realokasi belanja pemerintah pusat, penghematan belanja negara dari pos anggaran yang tidak mendesak dan belanja modal yang tidak prioritas selanjutnya dialihkan dalam bentuk pemenuhan infrastruktur kesehatan, jaring pengaman sosial, dan stimulus ekonomi untuk dunia usaha. Pada sisi lain, defisit anggaran berjalan tidak dapat dihindarkan dan diprediksi melebihi ambang batas maksimal yang ditetapkan undangundang tentang keuangan negara.

Kajian ini juga membuktikan bahwa pada situasi yang abnormal dimana anggaran negara mendapat tekanan luar biasa selama masa pandemi pemerintah dapat mengatasi krisis sosial ekonomi yang lebih dalam dengan menempuh langkah extraordinary sebagai terobosan luar biasa berupa perumusan dan implementasi kebijakan memperluas defisit anggaran demi penyelematan ekonomi dan sistem keuangan. Langkah luar biasa yang memang diperlukan untuk mengamankan anggaran negara disertai dengan evaluasi akuntabel dan transparan dengan tujuan terhindar dari krisis dengan skenario berat atau bahkan skenario sangat berat, kemudian setelah dapat melewati fase kritis tersebut secara bertahap fokus pada pemulihan ekonomi nasional.

\section{IMPLIKASI DAN KETERBATASAN}

Implikasi dari penelitian ini menunjukkan bahwa Pemerintah Pusat melalui Kementerian Keuangan harus melakukan berbagai upaya melindungi kesehatan masyarakat dan mengambil langkah-langkah strategis dalam tata kelola anggaran sebagai upaya untuk meminimalisir dampak Covid-19 terhadap keterpurukan ekonomi masyarakat, sektor UMKM dan Industri pada umumnya. Jurus extraordinary ditempuh melalui kebijakan pelebaran defisit fiscal tidak dapat dihindari pada situasi yang serba tidak menentu di tengah pandemi. Alokasi anggaran selanjutnya difokuskan pada perbaikan berdimensi ekonomi. Pengawasan pada eksekusi anggaran perlindungan kesehatan, bantuan sosial, dan pemulihan dunia usaha harus dilakukan secara ekstra ketat demi menjaga akuntabilitas dan kepercayaan publik. Keterbatasan akses data di tengah pandemi dengan mengakses data sekunder tahun 2019 dan data tahun 2020. Disarankan kepada peneliti lain melakukan penelitian lanjutan untuk memonitor dan mengevaluasi pertumbuhan ekonomi semester 2 dan dampaknya pada sektor perekonomian secara umum. 


\section{DAFTAR PUSTAKA}

Atkeson, A. (2020). What will be the economic impact of covid-19 in the us? rough estimates of disease scenarios. National Bureau of Economic Research.

Atmadja, A. P. S. (1986). Mekanisme pertanggungjawaban keuangan negara: suatu tinjauan yuridis. Gramedia.

Badan Kebijakan Fiskal. (2020). Pemerintah Upayakan Bantuan Sosial Efektif dan Tepat Sasaran di Masa Pandemi Covid-19. Diakses dari https://fiskal.kemenkeu.go.id/baca/2020 /05/03/150626860665310-pemerintahupayakan-bantuan-sosial-efektif-dan-tepatsasar pada 13 Februari 2021.

Bank Indonesia. (2020). Perkembangan Terkini Perekonomian dan Langkah BI dalam Hadapi Covid-19.

Bowen, G. A. (2009). Document analysis as a qualitative research method. Qualitative Research Journal, 9(2), 27.

BPS. (2020). Analisis Hasil Survey Dampak Covid-19 Terhadap Pelaku Usaha. Www.BPS.Go.Id.

Chang, C.-L., \& McAleer, M. (2020). Alternative global health security indexes for risk analysis of covid-19. International Journal of Environmental Research and Public Health, 17(9), 3161

CNN Indonesia (2020). Resep Vietnam Berhasil Buka Lockdown Tanpa Kasus Meninggal. Diakses dari https://www.cnnindonesia.com/ internasional/20200425084602-106497169/resep-vietnam-berhasil-bukalockdown-tanpa-kasus-meninggal pada tanggal 13 Februari 2021.

Creswell, John W. (2014). Research design: qualitative, quantitaive, and mixed methods approaches. Los Angeles: SAGE Publications.

DetikFinance.com. (2020). Sri Mulyani akui virus corona jadi ancaman fatal ekonomi RI. Diakses dari https://finance.detik.com/beritaekonomi-bisnis/d-4905982/sri-mulyani-akuivirus-corona-jadi-ancaman-fatal- ekonomi-ri pada tanggal 13 Februari 2021.

Eichenbaum, M. S., Rebelo, S., \& Trabandt, M. (2020). The macroeconomics of epidemics. National Bureau of Economic Research.

Engkus, N. S. (2020). Covid-19: kebijakan mitigasi penyebaran dan dampak sosial ekonomi di indonesia. Digital Library UIN Sunan Gunung Djati.

Falak, Ayman. (2020). Vietnam issues incentives to counter covid-19 impact, 15 April 2020. Diakses dari https://www.vietnambriefing. com/news/vietnam-issuesincentives-countercovid-19-impact.html/, diakses tanggal 13 Februari 2021.

Faridi, F. R. (1983). Theory of fiscal policy in an Islamic State. Journal of King Abdulaziz University: Islamic Economics, 1(1).

Granof, M. H., Khumawala, S. B., Calabrese, T. D., \& Smith, D. L. (2016). Government and not-forprofit accounting: Concepts and practices. John Wiley \& Sons.

Guerrieri, V., Lorenzoni, G., Straub, L., \& Werning, I. (2020). Macroeconomic Implications of COVID19: Can Negative Supply Shocks Cause Demand Shortages? National Bureau of Economic Research. [Google Scholar]

Hansen, D. R., \& Mowen, M. M. (2007). Managerial accounting 8th Edition. Ohio (USA): Thomson Wouth-Western.

Hausmann, R. (2020). Flattening the covid-19 curve in developing countries. Project Syndicate, 24. https://www.project-syndicate.org/ commentary/flattening-covid19-curve-indeveloping-countries-by-ricardo-hausmann2020-03 . [Google Scholar]

Huynh, Toan Lu Duc. (2020). The covid-19 containment invietnam: what are we doing? Journal of Global Health, 10(1), 1

IMF (International Monetary Fund). (2020a). World Economic Outlook, April 2020: The Great Lockdown. World Economic Outlook Reports. Washington, $\quad D C$ : IMF. Diakses dari https://www.imf.org/en/Publications/WEO/I ssues/2020/04/14/weo-april-2020 pada tanggal 13 Februari 2021.

IMF (2020b). Policy Responses to Covid-19, 25 mei 2020. Diakses dari https://www.imf.org/en/ Topics/imf-and-covid19/Policy-Responsesto-COVID-19 pada tanggal 13 Pebruari 2021.

Jaelani, A. (2018). Relasi negara dan pasar bebas dalam mewujudkan keadilan ekonomi: Analisis sejarah keuangan publik Islam. AlMustashfa: Jurnal Penelitian Hukum Ekonomi Syariah, 3(2), 169-186.

Katadata. (2020a). Bapennas: daya beli masyarakat hilang Rp362 T akibat pandemi corona. Diakses dari https://katadata.co.id/ agustiyanti/finansial/5ef09effcdd5c/bappena s-daya-beli-masyarakat-hilang-rp-362-takibat-pandemi-corona pada tanggal 13 Februari 2021.

Katadata. (2020b). Imbas PSBB, produksi manufaktur turun tajam sepanjang sejarah. Diakses dari https://katadata.co.id/ekarina/ berita/5eb15e42d698f/imbas-psbb-produksimanufaktur-turun-tajam-sepanjang-sejarah 
pada tanggal 13 Februari 2021.

Kementerian Keuangan. (2020). Media briefing: program pemulihan ekonomi nasional. Diakses dari https://www.kemenkeu.go.id/media/ 15116/media-briefing-kabkf.pdf pada 13 Februari 2021.

Mankiw, N. G. (2009). Macroeconomic (7th Edition). Worth Publishers.

McKibbin, W. J., \& Fernando, R. (2020). The global macroeconomic impacts of covid-19: seven scenarios. CAMA Working Paper 19/2020, Centre for Applied Macroeconomic Analysis (CAMA), Crawford School of Public Policy, Australian National University, Canberra. Diakses dari https://cama.crawford.anu.edu. $\mathrm{au} /$ sites/default/files/publication/cama_craw ford_anu_edu_au/2020-03/19_2020_ mckibbin_fernando_0.pdf pada tanggal 13 Februari 2021.

Merdeka. (2020). Data terkini jumlah virus corona di Indonesia. Diakses dari https://www. merdeka.com/peristiwa/data-terkini-jumlahkorban-virus-corona-di-indonesia.html pada tanggal 28 Maret 2021.

Milne, G. J., \& Xie, S. (2020). The effectiveness of social distancing in mitigating covid-19 spread: a modelling analysis. MedRxiv.

Muro, Whiton \& Maxim (2020). Covid-19 is hitting the nation's largest metros the hardest making a "restrat" of the economy more difficult. Diakses dari https://www.brookings.edu/ blog/the-avenue/2020/04/01/why-it-will-be difficult-to restart-the-economy-after-covid19/ pada tanggal 13 Februari 2021.

Musgrave, R. A. (1989). Public finance in theory and practice. McGraw-Hill.

Rossen, H.S. \& Gayer, T. (2008). Public finance. Diakses dari http://www.fintp.hr/upload/ files/ftp/2008/1/primorac.pdf pada tanggal 13 Februari 2021.

Sheiner, L. Belz, S. (2020). How will the coronavirus affect state and local government budgets? BrookingsInstitution. https://www. brookings.edu/blog/upfront/2020/03/23/ho w-will-the-coronavirus-affect-state-and-localgovernment-budgets/Google Scholar

Skjesol, G \& J. Tritter. (2020). The Covid-19 pandemic in Norway: the dominance of social implication in framing the policies response. Health Policy Technol, 9(4), 663-672. doi 10.1016/j.hlpt.2020.08.004

Suparman, N., Chandra, D., \& Sari, A. L. (2019). Bureaucratic behavior in the implementation of capital expenditure budget in the office of public work and spatial planning of Sumedang regency. Jurnal Bina Praja: Journal of Home Affairs Governance, 11(1), 99-109.

Suparmoko, M. (2013). Keuangan Negara, Dalam Teori dan Praktek (6th ed.). Yogyakarta: BPFE.

Theguardian. (2020). "Do not let this fire burned": WHO warns Europe over covid-19. Diakses dari. https://www.theguardian.com/word/2020/ mar/13/europen-countries-take-radicalsteps-to-combat-coronavirus pada tanggal 13 Februari 2021.

Tombe,T.(2020). The need to review Canada's fiscal stabilization program for provinces after Covid-19. Diakses dari https://cwf.ca/wpcontent/uploads/2020/08/2020-08-06-

CWF_IFRC_WhatNowPolicyBrief_CanadaFiscal StabilizationProgram_WEB.pdf pada tanggal 13 Februari 2021

Ulbrich, H. (2003). Public finance in theory and practice. London and New York: Rourledge..

Walker, P. G. T., Whittaker, C., Watson, O. J., Baguelin, M., Winskill, P., Hamlet, A., Djafaara, B. A., Cucunubá, Z., Mesa, D. O., \& Green, W. (2020). The impact of COVID-19 and strategies for mitigation and suppression in low-and middleincome countries. Science.

Worldbank.org. (2020). Prospek Ekonomi Indonesia, Juli 2020: Jalan Panjang Pemulihan Ekonomi. Diakses dari https://www.worldbank.org/ in/country/indonesia/publication/july-2020indonesia-economic-prospect pada tanggal 13 Februari 2021. 
Lampiran 1 Stimulus Ekonomi untuk Penanganan Covid-19 di Indonesia

\begin{tabular}{|c|c|c|c|}
\hline No & $\begin{array}{l}\text { Bentuk } \\
\text { Stimulus }\end{array}$ & $\begin{array}{c}\text { Jenis } \\
\text { Stimulus }\end{array}$ & Deskripsi dan Tujuan Stimulus \\
\hline \multirow{5}{*}{1} & \multirow{5}{*}{$\begin{array}{l}\text { Stimulus } \\
\text { Fiskal }\end{array}$} & $\begin{array}{l}\text { Keringanan pembayaran } \\
\text { (PPh), pasal } 21\end{array}$ & $\begin{array}{l}\text { Membantu likuiditas pekerja pada sektor industri } \\
\text { selama jangka waktu enam bulan. }\end{array}$ \\
\hline & & $\begin{array}{l}\text { Relaksasi pajak } \\
\text { penghasilan (PPh)pasal } 22\end{array}$ & $\begin{array}{l}\text { Memberi ruang cash flow sebagai kompensasi } \\
\text { switching cost. Selama jangka waktu enam bulan }\end{array}$ \\
\hline & & $\begin{array}{l}\text { Penguranagan pajak } \\
\text { penghasilan (PPh) pasal } 25 \\
\text { sebesar } 30 \text { persen. }\end{array}$ & $\begin{array}{l}\text { Memberi ruang cash flow sebagai kompensasi } \\
\text { switching cost. Selama jangka waktu enam bulan }\end{array}$ \\
\hline & & $\begin{array}{l}\text { Restitusi pajak pendapatan } \\
\text { (PPn) }\end{array}$ & $\begin{array}{l}\text { Diberlakukan dengan sasaran membantu likuiditas } \\
\text { perusahaan. }\end{array}$ \\
\hline & & $\begin{array}{l}\text { PPh Final PP no. } 23 \text { tahun } \\
2018 .\end{array}$ & $\begin{array}{l}\text { Relaksasi selama } 6 \text { bulan atas PPh Final PP No.23 } \\
\text { tahun 2018. Meringankan beban pengusaha } \\
\text { khususnya pada sektor UMKM. }\end{array}$ \\
\hline \multirow{4}{*}{2} & \multirow{4}{*}{$\begin{array}{l}\text { Stimulus Non } \\
\text { Fiskal }\end{array}$} & $\begin{array}{l}\text { Penyederhanaan larangan } \\
\text { terbatas (Lartas) ekspor }\end{array}$ & $\begin{array}{l}\text { Deregulasi produk ekspor. Kelengkapan dokumen } \\
\text { merujuk pada dokumen utama saja. }\end{array}$ \\
\hline & & $\begin{array}{l}\text { Penyederhanaan larangan } \\
\text { terbatas (Lartas) impor }\end{array}$ & $\begin{array}{l}\text { Bertujuan untuk meningkatkan kelancaran } \\
\text { impordan ketersediaan bahan baku. }\end{array}$ \\
\hline & & $\begin{array}{l}\text { Percepatan prosen ekspor- } \\
\text { impor untuk Reputable } \\
\text { Trader }\end{array}$ & $\begin{array}{l}\text { Pembedaan perlakuaan layanan /pengawasan } \\
\text { kepada } 625 \text { perusahaan Mitra Utama Kepabeanan } \\
\text { (MITA) dan } 109 \text { perusahaan Authorized Economic } \\
\text { Operator (AEO). }\end{array}$ \\
\hline & & $\begin{array}{l}\text { Percepatan prosen ekspor- } \\
\text { impor secara umum }\end{array}$ & $\begin{array}{l}\text { Pengusaha dapat melakukan pengurusan melalui } \\
\text { mekanisme National Logistics Ecosystem }\end{array}$ \\
\hline \multirow{4}{*}{3} & \multirow{4}{*}{$\begin{array}{l}\text { Stimulus } \\
\text { Sektor } \\
\text { keuangan }\end{array}$} & $\begin{array}{l}\text { Kebijakan perbankan } \\
\text { untuk } \\
\text { Mendukung stimulus } \\
\text { pertumbuhan ekonomi } \\
\text { termasuk debitur UMKM }\end{array}$ & $\begin{array}{l}\text { Dilakukan untuk mendorong optimalisasi fungsi } \\
\text { intermediasi perbankan. Assesmen mutu } \\
\text { kredit/pembiayaan/penyediaan dana lain mengacu } \\
\text { pada indikator berupa ketepatan pembayaran pokok } \\
\text { dan/atau bunga untuk kredit s.d Rp10 miliar }\end{array}$ \\
\hline & & $\begin{array}{l}\text { Kebijakan restrukturisasi } \\
\text { debitur UMKM secara lebih } \\
\text { fleksibel. }\end{array}$ & $\begin{array}{l}\text { Menjaga stabilitas sistem keuangan. Bank dapat } \\
\text { melakukan restrukturisasi untuk seluruh } \\
\text { kredit/pembiayaan tanpa melihat batasan plafon } \\
\text { kredit atau jenis debitur, termasuk debitur UMKM. } \\
\begin{array}{l}\text { Kualitas kredit/pembiayaan yang dilakukan } \\
\text { restrukturisasi ditetapkan lancar } \\
\text { direstrukturisasi }\end{array} \\
\end{array}$ \\
\hline & & $\begin{array}{l}\text { Mendorong Pemberdayaan } \\
\text { UMKM }\end{array}$ & $\begin{array}{l}\text { Mendukung pertumbuhan ekonomi terutama sektor } \\
\text { Usaha Mikro, Kecil dan Menengah (UMKM). } \\
\text { Melakukan restrukturisasi kredit/pembiayaan } \\
\text { UMKM. }\end{array}$ \\
\hline & & Insentif Pekerja & $\begin{array}{l}\text { Insentif relaksasi pada Program Badan } \\
\text { Penyelenggara Jaminian Sosial Ketenagakerjaan (BP } \\
\text { Jamsostek) kepada pekerja untuk mengantisipasi } \\
\text { tertular corona. }\end{array}$ \\
\hline
\end{tabular}

Sumber: Peraturan Menteri Keuangan No.23/PMK.03/2020 